\title{
Türkçenin İkinci Dil Olarak Öğretiminde Söz Varlı̆̆ının Sözlük Okuma Yoluyla Geliştirilmesi Üzerine Öğrenci Görüşlerinin Değerlendirilmesi ${ }^{1}$
}

Ali Göçer²

\author{
Bilal Ferhat Karadağ $\breve{3}^{3}$
}

Type/Tür:

Research/Araştırma

Received/Geliş Tarihi: March

15/ 15 Mart 2021

Accepted/Kabul Tarihi:

November 17/ 17 Kasim 2021

Page numbers/Sayfa No: $1672-$

1695

Corresponding

Author/İletişimden Sorumlu

Yazar:

ferhatkaradag58@gmail.com

\section{$\checkmark$ iThenticate}

This paper was checked for plagiarism using iThenticate during the preview process and before publication. / Bu çalışma ön inceleme sürecinde ve yayımlanmadan önce iThenticate yazılımı ile taranmıştır.

\section{Copyright $@ 2017$ by}

Cumhuriyet University, Faculty of Education. All rights reserved.

\section{Öz}

Bireyler, sözcük hazinelerinin zenginliği ölçüsünde duygu ve düşüncelerini ifade edebilmektedirler. Çünkü verimli bir iletişim kurabilmenin şartlarından biri de kişinin sözcük hazinesinin fazlalığıdır. Bu verimli iletişimi sağlayan ise kişinin aktif sözcük hazinesidir. Günümüzde bireylerin aktif sözcük hazinesini geliştirmek için çeşitli yöntem ve teknikler uygulanmaktadır. Çok fazla gündemde olmasa da sözlük okuma yöntemi de bunlardan bir tanesidir. Bu çalışmanın amacı, Türkçenin ikinci dil olarak öğretiminde söz varlığının sözlük okuma yoluyla geliştirilmesini B2 ve sonraki düzeylerdeki öğrenci görüşlerine göre değerlendirmektir. Çalışma nitel araştırma yöntemi çerçevesinde durum çalışması deseniyle gerçekleştirilmiştir. Araştırma, 2019 yılında TÖMER kurumunda gerçekleştirilmiş ve çalışmaya bu TÖMER'de öğrenim görmekte olan on yabancı öğrenci katılmıştır. Araştırmanın verileri yarı açık uçlu sorulardan oluşan yarı yapılandırılmış görüşme formu ve video kayıtları ile toplanmıştır. Elde edilen verilerin analizi içerik analiziyle gerçekleştirilmiştir. Yapılan görüssmeler ve tutulan video kayıtları neticesinde, sözlük okuma yoluyla katılımcıların sözcük hazinelerinin geliştirilebildiği, öğrencilerin sözlük okuma sürecine katılım oranlarının yüksek olduğu ve sözlük kullanma yeterliklerinin fazla olduğu gibi bulgulara ulaşılmıştır. Ulaşılan bulgulardan yola çıkılarak, Türkçenin ikinci dil olarak öğretiminde B2 ve sonraki düzeylerdeki öğrencilerin sözcük hazinelerinin geliştirilebilmesi için sözlük okuma yönteminden faydalanılabileceği ve öğrencilerin sözcüklerin birden çok anlamını öğrenmeleri isteniyorsa yine sözlük okuma yoluna gidilebileceği gibi öneriler, öğrenci görüşlerinden hareketle sonuç kısmında sunulmuştur.

Anahtar Kelimeler: Sözlük, sözlük okuma, söz varlığı, sözcük hazinesi, Türkçenin ikinci dil olarak öğretimi

\section{Suggested APA Citation/Önerilen APA Atıf Biçimi:}

Göçer, A., \& Karadağ, B. F. (2021). Türkçenin ikinci dil olarak öğretiminde söz varlığının sözlük okuma yoluyla geliştirilmesi üzerine öğrenci görüşlerinin değerlendirilmesi. Cumhuriyet International Journal of Education, 10(4), 1672-1695. http:// dx.doi.org/10.30703/cije.897062

\footnotetext{
${ }^{1}$ Bu çalışma, 26-27 Nisan 2019 tarihlerinde Gaziantep'te düzenlenen “6. Uluslararası Multidisipliner Çalışmaları Kongresi" nin bildiri kitabında basılan çalışmanın geliştirilmiş ve genişletilmiş halidir.

2 Prof. Dr., Erciyes Üniversitesi, Eğitim Fakültesi, Türkçe Eğitimi ABD, Kayseri/Türkiye

Prof. Dr., Erciyes University, Faculty of Education, Department of Turkish Education, Kayseri/Turkey e-mail: gocerali@gmail.com ORCID ID: orcid.org/0000-0002-6880-2611

${ }^{3}$ Arş. Gör., Erzincan Binali Yıldırım Üniversitesi, Eğitim Fakültesi, Türkçe Eğitimi ABD, Erzincan/Türkiye Res. Assist., Erzincan Binali Yildirim University, Faculty of Education, Department of Turkish Education, Erzincan, Turkey. e-mail: ferhatkaradag58@gmail.com ORCID ID: $\underline{\text { orcid.org/0000-0002-5301-2860 }}$
} 


\title{
Evaluation of Students' Views on the Development of Vocabulary through Reading Dictionary in Teaching Turkish as a Second Language
}

\begin{abstract}
Individuals can express their feelings and thoughts to the extent of wealth of word treasures. Because one of the conditions for establishing efficient communication is the excess of the vocabulary. This is the active vocabulary of the person who provides efficient communication. Various methods and techniques are applied to develop the active vocabulary of individuals. The method of reading the dictionary is one of these, although it is not on the agenda. The aim of this study is to evaluate the development of vocabulary through dictionary reading in teaching Turkish as a second language according to the views of students at B2 and higher levels. The study was carried out with the study of case study within the framework of qualitative research method. The study was carried out, in 2019, TÖMER and ten foreign students attended. The data of the study was collected by semi-structured interview form and video recordings. The data were analyzed by content analysis. As a result of the interviews and the video recordings, it was concluded that participants' vocabulary could be improved through dictionary reading, students' participation in the dictionary reading process was high, and their ability to use the dictionary was high. Based on the findings, suggestions were presented in the conclusion part, based on the students' opinions, such that the dictionary reading method can be used to improve the vocabulary of students at B2 and higher levels in teaching Turkish as a second language, and if students are required to learn more than one meaning of the words, they can also use the dictionary reading.
\end{abstract}

Keywords: Dictionary, dictionary reading, vocabulary, vocabulary, teaching Turkish as a second language.

\section{Giriş}

Bireylerin duygu ve düşüncelerini ifade edebilmesinde sahip oldukları hatiplik yeteneği kadar sözcük hazinelerinin de önemi vardır. "Dili etkili, güzel ve doğru bir biçimde kullanabilmede bireyin sahip olduğu kelime hazinesinin önemi büyüktür." (Göçer, 2010, s. 1008). Çünkü kişiler, gündelik yaşamlarında sözcük hazineleri ne kadar zenginse, bu zenginlik ölçüsünde verimli bir iletişim kurabilmektedirler. Bu verimli iletişimi de sağlayan bireyin aktif sözcük hazinesidir. Bilindiği gibi "Kişinin sözlü ve yazılı anlatım becerilerinde bilinçli olarak kullandığı kelimeler 'aktif kelime hazinesi'ni; anlatım faaliyetlerinde kullanamadığı fakat okuma ve dinleme becerilerinde karşılaştığında anlamlandırabildiği kelimeler 'pasif kelime hazinesi'ni oluşturur." (Güney ve Aytan, 2014, s. 619). Bu açıdan düşünüldüğünde kişinin her türlü yaşam alanında varlığını aktif sözcük hazinesiyle devam ettirdiği görülmektedir. Çünkü aktif kelime hazinesi hem okunanı hem de duyulanı idrak edebilmeyi kolaylaştırmaktadır. Pasif kelime hazinesinin, aktif kelime hazinesinin dört katı olduğu (Jalongo ve Sobolak, 2011) düşünüldüğünde de aktif kelime hazinesini zenginleştirmenin önemi daha net görülmektedir. Çünkü bireylerin pasif sözcük hazinesinde kalarak aktif sözcük hazinesine geçmeyen sözcükler, bireylerin bu sözcüklerden üst düzeyde faydalanabilmesini güçleştirmektedir. O hâlde çeşitli öğretim etkinliklerinin tasarlanarak kişilere kazandırılması ve bu etkinlikler sonrasında da tamamlayıcı etkinlikler gerçekleştirilerek sözcüklerin kalıcılığının sağlanması gerekmektedir. Çünkü Scmitt (2008), üretken olarak kullanılacaksa, 
kişilerin kelimelerin anlamı ve derinliği hakkında bilgilendirilmeleri gerektiğini belirtmektedir.

Bireylerin aktif sözcük hazinesini geliştirebilmek için çeşitli etkinlikler yapılmaktadır. McCarten (2007) sözcük öğretiminde en etkili yolun bağlamdan hareketle öğretim olduğunu belirtmektedir. Yani ilk defa karşılaşılan bir sözcügüün hemen anlamı söylenmemeli, öğrencinin o sözcügü metnin veya cümlenin bağlamindan hareketle tahmin etmesi yoluna gidilmelidir. Bu sayede sözcüğün hatırlanma ve kalıcılık düzeyinin yüksek olacağı düşünülmektedir. Bağlamdan hareketle sözcük öğretiminin yanında başka tür etkinlikler de kullanılabilmektedir. Karatay (2004), sözcük öğretiminde kolay ve yaygın olarak yaptırılabilecek etkinlikleri şöyle sıralamıştır:

- Öğrencilere, öğrendiği her sözcük için bir sözlük tutturmak.

- Sözlük aldırtıp kullanımını özendirmek.

- Öğrencilere, gündelik yaşamda kullanım oranı yüksek, sosyal yaşamında fazlaca karşılaşabileceği sözcükleri öncelikli olarak öğretmek.

- Eğer öğretilecek kelime eyleme veya işe dayanıyorsa bu eylemi uygulayarak açıklamasını yapmak.

- Aktif olarak kullanılmayan sözcüklerin unutulmasını engellemek amaciyla seviyeye uygun kitaplar belirleyerek öğrenciler arasında okunmasını sağlamak.

- Öğretilecek sözcüğü doğrudan açıklama yoluna gitmeden önce çeşitli jest ve mimiklerle açıklamaya çalışmak.

Görüleceği üzere farklı yöntem ve teknikler, sözcük öğretimi noktasında araştırmacılar tarafından belirtilmektedir. "Fakat kelimelerin farklı anlamları, özellikleri, cümle ve metin içinde kullanımı, günlük yaşamda kelimelerden nasıl yararlanılacağı, çeşitli becerileri geliştirmek için nasıl kullanılacağına yönelik çalışmalar üzerinde fazla durulmamıştır." (Güneş, 2013, s. 7). Sözlüklerden istifade edilmesi ve bu sözlüklerin öğrenciler tarafından okunmasının sağlanmasının, öğrenilen sözcüklerin öğrencilerin aktif sözcük hazinelerinde kalıcı olabileceği düşünülmektedir. Ayrıca bu sayede sözcüklerin farklı anlamlarının ve farklı özelliklerinin kavranmasına olanak sağlanılabilecektir.

Sözlük, "Bir dilin kelimelerinin bütününü veya belli bir kısmını, deyimlerini alfabe sırasına, bazen de konu veya kavramlarına göre anlamlandıran, açıklayan veya başka dillerdeki karşılıklarını veren eserdir." (Ayverdi, 2011, s. 1128). Sözlük, anlama becerilerin geliştirilmesinin yanında, kişilere sözcüklerin daha derin ve farklı anlamlarını da sunabilmektedir. Böylelikle okuyucular, sözcüklerin sadece görünür anlamlarını değil, ilk bakışta akla gelmeyen arka plandaki anlamlarına da ulaşabilmektedirler. Çünkü sözlükler, "Bir dilin (ya da birden çok dilin) sözvarlığını, söyleyiş biçimleriyle, yazımlarıyla veren, bağımsız biçimbirimleri temel alarak bunların başka öğelerle kurdukları söz öğeleriyle birlikte anlamlarını, değişik kullanımlarını gösteren sözvarlığı kitabıdır." (Aksan, 1998, s. 75). Yani sözlükler, basit olarak sadece sözcük anlamını vermekle kalmayıp, aynı zamanda bir dilin inceliklerini ve anlatım gücünü gösteren eserlerdir. Dolayısıyla bu zenginlikteki eserlerin bir başvuru ya da başucu kitabı olarak düşünülmesi de normal karşılanmaktadır. Fakat günümüzde sözlüklerin hak ettikleri değeri görüp görmediklerine dair tartışmalar bulunmaktadır. Balaban (2014), sözlüklerin günümüzde eskisi kadar kıymet görmediğini belirtip sözlüklerin "bakılıp geçilen bir vitrin gibi değil, içinde uğraş ve 
çalışmanın yapıldığı bir mutfak gibi" olması gerektiğini ifade etmektedir. Çünkü Li (1998) bu eserlerin özellikle dil eğitimi için en başarılı ve vazgeçilemeyecek yapıtlar olduğuna dikkat çekmektedir. Hâliyle ortaya "Sözlükler, bir başvuru kitabı olarak bakılıp geçilmeli mi, yoksa bir roman okur gibi okunmalı mı?" sorusu ortaya çıkmaktadır.

Alanyazına bakıldığında bu konuyla ilgili en çok dikkat çeken araştırmayı Balaban'ın (2014) yapmış olduğu görülmektedir. "Sözlükler okunmalı mı yoksa sözlüklere bakılmalı mı?" sorusunu irdeleyen araştırmacı, sözlüklerin sadece kelimelerin anlamlarını veren bir yapıt olarak nitelendirilmemesi gerektiğini belirtmektedir. Geçmiş yaşantılara bakıldı̆̆ında hiçbir sözlüğü baştan sona kadar okumayan kişilerin var olduğunu ifade ederek, sözlüklerin sadece sözcük anlamina bakılıp bir kenara atılan eserler olduğundan yakınmıştır. Oysa ortada Divanü Lügâti'tTürk gibi bir eserin var olduğu düşünüldüğünde, bir kenara atma eyleminin geçersiz olacağını vurgulamaktadır. Sözlüklerin insanlara bazen roman ve hikâye bazen de bir şiir tadında sözcükler sunduğuna değinmektedir. Zaten Crystal ve Crystal (2000) de bir insanın eğer ıssız bir adaya düşerse, kurgusu sağlam bir edebî eseri yanına almaktansa iyi bir sözlüğü tercih etmesi gerektiğini vurgulamaktadır. Çünkü bir sözlük, pasif ve bilinen tarzda sonsuz sayıda sözcük sunabilmektedir. Bu da bireyin bu sözcüklerle hayal kurabilmesine fırsat vermektedir. Bu hayal dünyasında ise sınırlayıcı etken kişinin sadece kendi hayal gücü olmaktadır. Hâliyle sözlüklerin, basit bir şekilde, sadece sözcüklerin anlamına bakmak için var olduğunu düşünmek yanlış bir davranış olacaktır. Çünkü “Kişi adları sözlüğünden, bitki adları sözlüğüne, felsefe sözlüğünden, tıp sözlüğüne, atasözleri sözlüğünden genel dil sözlüğüne kadar birçok çeşidi göz önüne alındığında sözlüklerin ne kadar geniş bir hazine olduğu anlaşılacaktır." (Korkmaz, 1999, s. 459). O hâlde sözlüklerin geniş anlam evreni düşünüldüğünde, sözlük okumanın önemli ve sözcük öğrenimi için gerekli bir eylem olduğu görülmektedir.

"Sözlük okuma meselesi maalesef müstakil bir konu olarak şimdiye kadar ele alınmış değildir. Oysa bu konu şimdiye kadar çoktan tartışılmalıydı." (Balaban, 2014, s. 241). Çünkü sözlük okuma kişinin anlamlandırma yeteneğine katkıda bulunmaktadır. Okunan her sözcük, gerek kullanım alanıyla gerekse birden fazla anlama sahip olabilmesiyle insanların düşünme yeteneklerine derinlik katmaktadır. Nitekim sözlük okuma eyleminin katkılarının farkında olup uzun süredir bu eylemi gerçekleştiren bireyler de bulunmaktadır. Örneğin Kaplan (2011, s. 34) “Günlük dil veya edebî dil, baştanbaşa bir kültür hazinesidir. Türkler içinde yaşadıkları her medeniyet çă̆ında dili halı gibi işlemişlerdir. Ben Kaşgarlı Mahmud'un Divanü Lügâti't- Türk'ünü roman gibi birkaç kere okudum." ifadeleriyle yerine göre sözlüklerin bir roman edasıyla okunabileceğini belirtmektedir. Çünkü sözlük okuma eylemi sanıldığı gibi sıradan bir okuma eylemine benzememektedir. İnsanlar için farklı kazanaımlar sunmaktadır. Bu kazanımlar da bireylerin günlük hayatında etkisini göstererek kişilere hitabet yeteneği kazandırabilmektedir. Örneğin bu durumla ilgili olarak İngiliz politikacı Arthur Scargill'in şöyle bir ifadesi vardır: "Babam hâlâ her gün sözlük okur. $\mathrm{O}$ 'Sizin hayatınız, bildiğiniz temel kelimelerin gücüne dayanır' demektedir.” (Hall, 2002). Öyleyse sözlükler, sahip oldukları değerli bilgiler aracılığıyla tıpkı bir roman ve hikâye gibi okunabilmektedirler. 
Balaban (2014), sözlük okumanın basit bir okuma biçiminde düşünülmemesi gerektiğini ifade etmektedir. Ona göre sözlükler okunmalıdır çünkü içerisinde ait olduğu dilin en değerleri hazinelerini barındırmaktadır. Öğretmenlerinin rehberliğiyle etkili okuma yapabilen öğrencilerin, sözlüklerin bünyesinde keşfedebilecekleri çok şey olduğunu vurgulamaktadır. Bu tarzdaki bir okumanın ise öğrencilerin ses bilgisi, dil ve edebiyat derslerine fayda sağlayacağını belirtmektedir. Ayrıca sözcük hazinelerini zenginleştirirken aynı zamanda sözlüklerin sistematiğini kavratacağını ve Türkçedeki sözcüklerin etimolojilerini öğreteceğini söylemektedir. Bununla beraber sözlüklerde bir sözcüğün nasıl işlendiğine ilişkin bilgi edinmeye olanak sağlayacağını ve sözcüklerin anlam bağlamını kavratacağını ifade etmektedir. Ek olarak sözlük okumanın sözcüklerin birleşik ve türemiş biçimlerini öğretebileceğini, madde başı ve alt madde olan sözcüklerin anlamlarındaki farklılıkları buldurtabileceğini bildirmektedir. Bununla beraber Türk edebiyatındaki ünlü simalara yönelik bir aşinalık kazandırılıbileceğini söylemektedir. Bu bakımdan düşünüldüğünde, sözlük okuma eyleminden Türkçenin ikinci dil olarak öğretiminde de faydalanılabileceği görülmektedir. Çünkü hedef dili öğrenmek isteyen bir kişi için gramer bilgisi ne kadar önemliyse sahip olduğu kelime hazinesi de kendini ifade edebilmesi açısından o kadar önemli olmaktadır. Yani “Sözcük dağarcığının genişliği, kişiye konuşma akıcılığı ve kolaylığı sağlar. Aynı zamanda bireyin diğer dil becerilerinin gelişimini de etkiler." (Büyükikiz ve Hasırcı, 2013, s. 148). Zaten Maskor ve Baharudin (2016) de öğrencilerin sözcük hazinelerinin zenginleştirilmesinin onlar için bir artı olacağını ve yabancı dil öğrenmek için verilen dikkatin artabileceğini belirtmektedir. Türkçenin ikinci dil olarak öğretiminde de öğrencilerin sözcük hazinelerinin zenginleştirilmesi anlama ve anlatma becerilerinin gelişmesi açısından önemli olarak görülmektedir. Bundan dolayı sistemli bir şekilde öğrencilere sözcük öğretiminin yapılması gerekmektedir.

Yabancı dil sözcük öğretimi sürecinde de aynı ana dili sözcük öğretimine benzer olan türlü yöntemler tercih edilmektedir. Bu yöntemler arasında sık başvurulanlar ise sözcüklerin direkt olarak anlamının paylaşılması, eş ve zıt anlamlarının üzerinde durulması, yapının bağlamından yola çıkarak sözcügüün anlamının ne olabileceğinin tahmin edilmesi, görselliğe başvurularak kavratılmaya çalışılması, jest, mimik ve beden hareketlerinden istifade edilmesidir (Barcroft, 2007; Fan 2003; Read, 2004; Schmitt, 2008). Ayrıca daha önce de belirtildiği gibi sözlük okuma yöntemine de bir alternatif olarak sözcük öğretiminde başvurulabilmektedir. Haliyle Türkçenin ikinci dil olarak öğretiminde sözlük okuma yöntemi de bireylerin sözcük hazinelerini geliştirebilmek amacıyla kullanılabilmektedir. Çünkü Nation (2005) sözcük hazinesini geliştirme durumu için vakit ayrılmasını ve sözcük öğretimi gerçekleştirilirken de sözcüğe ilişkin hangi unsurların öğretileceğinin belirlenmesi gerektiğini vurgulamaktadır.

Türkçenin ikinci dil olarak öğretiminde sözlüklere başvurmak, gerek sözcüğün derinliğinin artırılabilmesinde gerekse de öğrencilerin aktif sözcük hazinesinin geliştirilebilmesinde önemli görülmektedir. "Bu anlamda yabancı dil öğrenen bireyleri sözlük kullanmaya özendirme ve bu alışkanlığı kazandırma, kelime dağarcığının geliştirilmesi noktasında önemli bir rol oynamaktadır." (Halat ve Firat, 2021, s. 151). Çünkü sözcük hazinesi fazla olan öğrencilerin hedef dilde anlatılanları anlama, anladığını anlatma, kendisini ifade etme ve farklı bireylerle iletişim kurabilme becerisi 
gelişmektedir. Böylelikle dili daha iyi kullanabilen, dilsel ve bilişsel farkındalığı yüksek dil öğrenicileri oluşmaktadır. Sözlükler de bu becerilerin kazandırılmasında bir araç işlevi görmektedir. Türkçe öğrenmeye çalışan öğrencilerin bir başucu kaynağ1 olarak sözlüklere başvurması, onların doğrudan ve dolaylı olarak dili daha faydacı bir biçimde kullanmalarına olanak tanımaktadır. Artan kelime hazineleri sayesinde bir konuşma veya dinleme esnasında iletişimin gidişatına göre cümleler kurabilmekte ve kriz yönetimini başarılı bir biçimde gerçekleştirmesine olanak tanımaktadır. Bu sayede zaman kazanmak için boşluk dolduruculardan faydalanma, ifade edilmesi güç olan durumları başka kelimelerle izah etme ve konuşulan kişiden yardım talebinde bulunma (Brown, 2001, akt. Dağtan, 2015, s. 336) gibi çeşitli durumlara neden olabilecek ihtimallerin azaltılması mümkün olabilmektedir. Bununla beraber kullanılacak sözlüklerin türü de öğrenme sürecinin niteliği açısından önem arz etmektedir.

Türkçeyi ikinci dil olarak öğrenen öğrenci açısından bakıldı̆̆ında, Türkçenin sözcük hazinesine yönelik çeşitli sözcük ve sözcük gruplarıyla karşılaşabileceği görülmektedir. Dil öğrenimi esnasında bu unsurların birçoğuyla etkileşim içerisine giren öğrenciler, duruma göre farklı sözlük türlerine ihtiyaç duyabilmektedirler. Tüm (2017), Türkçe öğretilirken kullanılabilecek atasözleri ve deyimler sözlüğü, eş anlamlı sözlükler, kişi adları sözlüğü, terimler sözlüğü, derleme sözlüğü ve tarama sözlüğü gibi değişik işlevleri olan sözlüklerin bulunduğunu belirtmektedir. İhtiyaçlarına göre bahsi geçen sözlüklere başvuran öğrencilerin yalnızca mesaj iletmek için değil, aynı zamanda özerk öğrenmeyi gerçekleştirebilmek için bu sözlük türlerinden cesaret alabileceğini ifade etmektedir. Sistemli bir biçimde Türkçe öğrenen öğrenciler, belirli bir süre sonra daha işlevsel diyaloglar kurmak isteyebilecek ve dili farklı yönleriyle kullanma amacı güdebileceklerdir. Bundan dolayı sözcük öğretimi yaparken kullanılacak sözlüklerin çeşitlendirilmesi öğrenci başarısını artırabilecektir. Çünkü dil seviyesi artan öğrencilerin başvuracağı sözlükler ve sözcükler de değişebilecektir.

Alanyazın incelendiğinde sözlük, sözlük okuma ve sözlük kullanımına ilişkin çeşitli çalışmaların yapıldığı görülmektedir. Bu çalışmalar içerisinde öncelikle Balaban'ın (2014) bakmak gerekir. Araştırmacı, sözlüklerin basit biçimde sözcüklerin anlamını içeren eserler olarak görülmemesi gerektiğini vurgulayarak sözlüklerin titiz bir biçimde okunması gereken edebi yapıtlar olduğunu ifade etmiştir. Halat ve Fırat (2021) ise Türkçeyi yabancı dil olarak öğrenen öğrencilerin sözlük kullanımıyla ilgili olarak çeşitli ortamlardaki görüş ve tercihlerini araştırmış; çeşitli verilere ulaşarak sözlüklere ilişkin yapılması gereken öneriler sunmuşlardır. Tüm (2017), yabancı uyruklu bireylerin Türkçe öğrenme sürecindeki sözlük tercihlerini inceleyerek kullanılan sözlüklerin öğrenci ihtiyaçlarını karşılama durumunu, hangi sözcüklerin daha faydalı olduğunu ve sözlük türlerinin sözcük öğrenimindeki rolünü değerlendirmiştir. Çalışma sonucunda ise öğrencilein uygun sözlük kullanmada zorlandığını belirterek sözlük çalışmalarının artırılması gerektiği ifade etmiştir. Göçer ve Garip (2021), ortaokul öğrencilerini sözlükle tanıştırarak sözlüklerin kullanımıyla ilgili farkındalık oluşturmayı amaçladıkları çalışmada Türkçe dersi serbest okuma saatlerinde ortaokul dördüncü sınıf öğrencileriyle sözlük okuma etkinlikleri gerçekleştirmişlerdir. Araştırmanın sonucunda ise sözlük okumanın öğrencilerin sözcük dağarcığını geliştirdiği ve anlama-anlatma becerilerini desteklediği sonucuna ulaşmışlardır. Kardaş (2016), yabancı öğrencilerin Türkçe öğrenirken sözlüklerden 
yararlanma durumunu ortaya koymayı amaçladı̆̆ı çalışmasında öğrencilerin sözcüklerin anlamını öğrenmek için sözlüklere başvurduğu ve büyük çoğunlukla teknolojik sözlükler kullandıkları gibi sonuçlara ulaşmıştır.

“Dil seviyesi arttıkça sözlüklerin daha bilinçli kullanılması da gerekir. Çünkü dil düzeyleri arttıkça günlük konuşma dilinden ziyade akademik kavramların, terminolojinin, mecazların, atasözlerinin, deyimlerin kullanım alanının da genişlediği görülmektedir." (Kardaş, 2016, s. 519). Dolayısıyla Türkçenin ikinci dil olarak öğretiminde kullanılabilecek sözlükler belirlenirken öğrencinin dil seviyesine de dikkat etmek gerekmektedir. Başlangıç düzeyindeki bir dil öğrenicisinin başvuracağ1 sözlükle ileri seviyedeki bir öğrencinin kullanacağ1 sözlüklerin farklı olabileceğine dikkat etmek gerekmektedir. Dil seviyesi ilerlemiş olan bir öğrencinin günlük yaşamda sıkça karşılaştığı sözcüklere yer veren sözlüklerden ziyade daha soyut ve daha karmaşık sözcüklere yer veren sözlüklere ihtiyacı olabilecektir. Hâliyle seviyelere göre kullanılabilecek sözlüklerin belirlenerek öğretim ortamlarında kullanılması, öğrencilerin dili daha etkili ve verimli bir biçimde öğrenebilmesine de olanak tanıyabilecektir. Yani öğrencileri tanıyarak onların seviyelerine ve ihtiyaçlarına uygun sözlüklerden faydalanmak dil öğretiminde önemli bir husus olarak görünmektedir. Böylelikle "Yabancı dil öğreniminin vazgeçilmez eğitim araçlarından biri olan sözlükler, kullanıcılarını dikkate alarak tasarlandıkları takdirde gerçek ihtiyacı karşılayabilir hâle gelmektedirler." (Kolukısa, 2015, s. 668). O hâlde Türkçenin ikinci dil olarak öğretiminde nitelikli bir sözcük öğretimi gerçekleştirebilmek için hem sözcük öğretim yönteminin öğretimine hem de seçilecek sözlüklere dikkat edilmesi gerekmektedir. Böylelikle dil öğrenicilerinin verimli ve etkili bir iletişim kurabilmelerine olanak tanınabilinmektedir. Daha önceden de değinildiği gibi sözcük öğretimi gerçekleştirebilmenin yollarından bir tanesi de sözlük okuma yöntemidir. Fakat alanyazından da anlaşılacağı üzere, Türkçenin ikinci dil olarak öğretimi sürecinde sözlük okuma yönteminin söz varlığına etkisine yönelik öğrenci görüşlerinin alındığı daha önceden gerçekleştirilmiş bir çalışma bulunmamaktadır. Dolayısıyla Türkçenin ikinci dil olarak öğretiminde sözlük okumadan faydalanılmasının nasıl bir tablo oluşturacağını öğrenci görüşlerine göre belirlemek önemlidir. Tabii sözlükleri okuma ve anlamlandırma eylemi zor bir uğraşı olduğundan özellikle üst seviyelerde bunu gerçekleştirmek önemli olarak görülmektedir. Bundan dolayı da özellikle B2 ve sonraki düzeylerde sözlük okuma yoluna başvurulmasının dil seviyeleri bakımından daha uygun olduğu düşünülmektedir. Böylelikle uygulamanın ayrıntılı bir şekilde incelenmesi, öğrencilerin görüşleri ve video kayıtları yoluyla Türkçenin ikinci dil olarak öğretiminde sözlük okuma yönteminin söz varlığına etkisine yönelik öğrenci görüşleri alındığında nasıl bir tablonun ortaya çıkacağı saptanabilecektir. Çalışmanın alana katkısının ve diğer çalışmalardan farklılaşmasını sağlayanın da bu tablo olduğu düşünülmektedir.

Çalışmanın amacı, Türkçenin ikinci dil olarak öğretiminde söz varlığının sözlük okuma yoluyla geliştirilmesini B2 ve sonraki düzeylerdeki öğrenci görüşlerine göre değerlendirmektir. Bu amaç doğrultusunda şu alt amaçlara cevaplar aranmıştır:

1. Türkçeyi ikinci dil olarak öğrenenlerin sözlük okuma yöntemine yönelik görüşleri nelerdir? 
2. Türkçeyi ikinci dil olarak öğrenenlerin sözlük okuma yöntemi ile okunan sözcüklerin sayısına ilişkin görüşleri nelerdir?

3. Türkçeyi ikinci dil olarak öğrenenlerin sözlük okuma yöntemi ile okunan sözlüklere ve seviyeye uygunluğuna ilişkin görüşleri nelerdir?

4. Türkçeyi ikinci dil olarak öğrenenlerin sözlük okuma yönteminin devamlılığına ilişkin görüşleri nelerdir?

\section{Çalışmanın Deseni}

\section{Yöntem}

Araştırma, nitel araştırma yönteminin bir deseni olan durum çalışması deseni aracılığıyla gerçekleştirilmiştir. Bu desen, “Özellikle değerlendirme süreçleri gibi birçok alanda kullanılan, araştırmacının bir durumu, sıklıkla da bir programı, olayı, eylemi, süreci ya da bir veya daha fazla bireyi derinlemesine analiz ettiği bir araştırma desenidir." (Stake, 1995, Yin, 2009; akt. Creswell, 2014, s. 14). Yin (2009), dört tane durum çalışması deseninin var olduğunu belirtmektedir. Bu desenlerin ise bütüncül tek durum deseni, gömülü yani iliştirilmiş tek durum deseni, bütüncül çoklu durum deseni ve iliştirilmiş çoklu durum deseni olduğunu ifade etmektedir. Bu çalışmada ise bütüncül tek durum deseni tercih edilmiştir. Yıldırım ve Şimşek (2011) bu desenin isminden de anlaşılacağı gibi bir kurum, bir birey, bir program veya okul gibi yalnızca bir analiz birimine sahip olduğunu ifade etmektedir. Ortada güzel bir şekilde formüle edilmiş bir kuram bulunursa, bu kuramın doğrulanması veya olumsuz taraflarının açıklanabilmesi için bu desenin tercih edilebileceğini belirtmektedir. Bu çalışmada bütüncül tek durum deseninin tercih edilmesinde, katılımcılara bir dönem boyunca sözlük okuma yoluyla sözcük öğretiminin gerçekleştirilmeye çalışılması ve sözlük okumaya yönelik öğrencilerin görüşlerini değerlendirme çabası etkili olmuştur.

\section{Çalışma Grubu}

Çalışmanın katılımcıları, amaçlı örnekleme türlerinden biri olan kolay ulaşılabilir durum örneklemesine göre belirlenmiştir. Yıldırım ve Şimşek (2011), kolay ulaşılabilir durum örneklemesinin araştırmaya hız ve pratiklik sağladığını; bununla beraber araştırmayı gerçekleştirenlerin farklı bir örnekleme türünü tercih edebilmesinin zor olduğu durumlarda bu örnekleme türünü tercih edebileceklerini vurgulamışlardır. Bu çalışmada kolay ulaşılabilir durum örneklemesinin tercih edilmesinin nedeni ise, çalışmanın gerçekleştirildiği yerde ikinci dil olarak Türkçe öğretimini sistemli bir şekilde gerçekleştiren tek kurumun olmasından kaynaklanmaktadır. Yani araştırmacıların başka bir örneklem tercih etmeleri mümkün olamamaktadır. Bu sebepten ötürü araştırmanın çalışma grubunu Türkiye' de bir üniversitenin TÖMER kurumunda Türkçe öğrenmekte olan on öğrenci oluşturmuştur. Bu öğrenciler Türkçeyi kendi ülkelerinde değil de Türkiye'de öğrendikleri için ikinci dil öğrenicisi konumundadırlar. Ĕger öğretilen dil, öğretildiği ülkenin ana dili ise ikinci dil olarak kabul edilmektedir. Örneğin, Bir İngiliz'e Türkçe öğretimi Türkiye topraklarında gerçekleştiriliyorsa bu durumda Türkçe ikinci dildir (Şen, 2019). Bu on katılımcının yarısı kadın, diğer yarısı erkektir. Katılımcıların yaş grupları ise on sekiz ile yirmi altı arasındadır. Bu katılımcıların dil seviyesi ise B2 düzeyindedir. Çalışma 2019 yılında gerçekleştirilmiştir. Katılımcılara ait bilgilere aşağıdaki tabloda yer verilmiştir: 
Tablo 1

Katılımcilara İlişkin Bilgiler

\begin{tabular}{lcc}
\hline \multicolumn{1}{c}{ Katılımcının Mensup Olduğu Ülke } & Katılımcı Sayısı & Dil Seviyesi \\
\hline İran & 4 & B2 \\
Somali & 3 & B2 \\
Türkmenistan & 2 & B2 \\
Yemen & 1 & B2 \\
\hline
\end{tabular}

Çalışma grubunu oluşturan katılımcılar Türkiye'de yükseköğrenim görmek için bulunmaktadırlar. Bu kişiler eğitimlerine başlayabilmek amacıyla Türkçeyi C1 düzeyinde öğrenebilmek için TÖMER kurumunda eğitim görmektedirler.

\section{Veri Toplama Araçları}

Çalışmada birden fazla veri toplama aracı kullanılmıştır. Bu sayede bir tane veri toplama aracı kullanıldığında oluşabilecek olası problemlerin önüne geçebilmek amaçlanmıştır. Böylelikle hem çalışmanın geçerlik ve güvenirliğini artırmak hem de durum araştırması desenin klasik özelliği olan derinlemesine bilgiyi bulgular kısmında yansıtabilmek hedeflenmiştir. Bu bağlamda veri toplama araçları olarak görüşme ve video kayıtlarına başvurulmuştur.

Görüşme. Patton (2014) görüşme türünde amacın, bireylerin dünyayı nasıl gördüklerini kavramak, tercih ettikleri terminoloji ve yargıları öğrenmek ve bunlara ek olarak bireysel bakış açılarıyla deneyimlerinin karmaşıklığını belirleyebilmek olduğunu belirtmektedir. Çalışmada, katılımcıların sözlük okuma yoluyla sözcüklerin öğrenimine ilişkin görüşlerini belirleyebilmek amacıyla yarı yapılandırılmış görüşme türü kullanılmıştır. Merriam (2013), bu görüşme türünde görüşmenin çeşitli tekniklerle oluşturulması gerektiğine değinerek, görüşmede yer alacak soruların yapısının esnek cümlelerden meydana gelmesi gerektiğini belirtmektedir. Çalışmada da bu görüşme türünün araştırmacılara sağladığı esneklik artısından faydalanılmış ve katılımcı görüşlerine göre sorular yeniden oluşturulmuştur. Katılımcılardan izin alınarak görüşme süreci kayıt altına alınmış; böylelikle de muhtemel veri kaybının önüne geçilmek istenmiştir. Gerçekleştirilen görüşmelerin süresi yirmi iki ile yirmi yedi dakika arasında değişmektedir.

Görüşme süreci zarfında verileri toplayabilmek amacıyla yarı yapılandırılmış görüşme formu tercih edilmiştir. Bu form yarı açık uçlu sorulardan oluşmuş; amaca hizmet etmesi, anlaşılırlığ ve uygulanabilirliğini tespit etmek için üç alan uzmanının görüşüne sunulmuştur. Uzman önerileri ie üç sorunun sonda kısımları küçük çapta düzeltilmiştir. Daha sonra pilot uygulaması yapılarak son şekli verilmiştir.

Video kayıtları. Çalışmada tercih edilen bir diğer veri toplama aracı ise video kayıtlarıdır. Johnson (2015), video kayıtları aracılığıyla kişilerin sözel olmayan hareketlerine ve süreç boyunca bulundukları yer, davranış ve performansları ile ilgili bilgilere ulaşılabileceğini ifade etmektedir. Çalışmada, veri kaybını önleyerek verileri sonraki süreçte tekrar izleyebilmek ve sözlük okuma süreci boyunca meydana gelen olayların detaylı bir şekilde betimlemesini yapabilmek amacıyla video kayıtlarına başvurulmuştur. Böylelikle gözden kaçma olasılığı olan verilerin kaybı engellenerek, araştırmacılara detaylı inceleme şansı olanağı sağlanmıştır. 


\section{Verilerin Analizi}

Çalışmanın verilerini analiz edebilmek için içerik analizine başvurulmuştur. "İçerik analizi yoluyla verileri tanımlama ve verilerin içinde saklı gerçekleri ortaya çıkarma amaçlanmaktadır." (Gülbahar ve Alper, 2009, s. 100). Yani “İçerik analizi ile araştırma boyunca elde edilen verilerin kavramlar ve çeşitli temalar aracılığıyla yorumlanması hedeflenmektedir." (Karadağ ve Göçer, 2018, s. 439). Bu çalışmada da elde edilen verilerin, çeşitli kavramlar aracılığıyla okuyucuların anlayabileceği bir şekilde yorumlanması hedeflendiği için içerik analizinden faydalanılmıştır. Analiz boyutunda, veri seti ayrıntılı bir şekilde incelenerek ortaya çıkan tabloya göre bazı kod ve temalar türetilmiştir. Örneğin, katılımcı görüşlerine göre 'sözcük sayısı' isimli bir tema oluşturulmuş ve bunun altında 'yeterli' ve 'yetersiz' gibi kodlar meydana getirilmiştir. Bunula ilgili bir örnek verilirse, 'Kelime sayısı daha fazla olabilir. Öğrenmemiz gereken çok şey olduğu için dersi merakla bekledim.' cümlesi sözcük sayısı teması altında değerlendirilmiş ve bu cümleden yetersiz kodu türetilmiştir. Bulgular kısmında katılımcıların ifadelerinden bahsedilirken kişilerin gerçek isimleri kullanmak yerine takma isimlerin kullanılmasına karar verilmiştir (Bahar, Ramazan, Türkan gibi).

\section{Geçerlik ve Güvenirlik}

Çalışmada çeşitli önlemler alınarak geçerlik ve güvenirlik konusunda zedelenme yaşanmamasına dikkat edilmiştir. Buna göre, ilk olarak çalışılan durumla ilgili olarak etkileşim süresi uzun tutulmuştur. Bu sayede sözlük okuma yönteminin uygulandığı öğrenme ortamlarında yapılan video kayıtlarının fazla olması hedeflenmiştir. Buna ek olarak veri çeşitlemesi yapılmış ve toplanan verilerin birbirlerine paralel ve teyit edici rolde olmasına önem verilmiştir. Daha sonra ise analiz edilen verilerle sonuçlar katılımcılarla paylaşılmış; transkript işleminin doğruluğu ve tutarlılığı incelenmiştir. Zaten Yıldırım ve Şimşek (2011) de katılımcıların fikirlerini almanın bir problem oluşturmayacağını, aksine alınan bu fikirlerin durumu, en iyi ölçüde doğru ve yansız bir biçimde betimlemeye olanak vereceğini belirtmektedir. İlerleyen süreçte ise alandaki üç uzmana sonuçlar gösterilmiş ve bu sonuçlarla ilgili görüşleri sorulmuştur. Böylelikle veri toplama araçlarıyla elde edilen bulgulardan ulaşılan sonuçların desteklenmesi hedeflenmiş ve bu uzmanların varsa olası görüşlerini belirlemek amaçlanmıştır. Kodlama sürecinde bireyselliği engelleyebilmek için veri setinin bir bölümü başka kodlayıcılar aracılığıyla kodlanmıştır. Bu sayede kodlama konusunda birlik oluşturulmuştur. $\mathrm{Bu}$ kodlayıcıların arasında var olan kolerasyonu saptayabilmek için "Güvenirlik = Görüş birliği / (Görüş Birliği + Görüş Ayrılığ1) x 100" formülünden faydalanılmıştır (Miles ve Huberman, 1994). Bahsi geçen formül bu çalışmada uygulandığında çalışmanın güvenirliği 0.91 olarak bulunmuştur. Miles ve Huberman (1994) güvenirlik sonucunun 0.70 ve üstünde olması gerektiğini belirttikleri için çıkan sonucun çalışmayı güvenilir olarak nitelediği anlaşılmaktadır. Son aşamada ise çalışmanın sonuçları, alanyazındaki diğer çalışmalarla benzerlik ve farklılıkları açısından uygun şekilde tartışılmıştır.

\section{Uygulama Süreci}

TÖMER'de bir kur boyunca, haftada iki gün olmak üzere katılımcı öğrencilerle sözlük okumaları gerçekleştirilmiştir. Okunan sözcük grubu, genel itibariyle gündelik ve sosyal yaşamda kullanım sıklığ1 fazla olan sözcüklerden oluşmuştur. Çalışmada 
toplamda 40 sözcüğün okuması gerçekleştirilmiştir. İlk hafta üçer sözcüğün okunması ile başanmış, daha sonraki süreçte bu sayı sırasıyla dört ve beşe çıkarılmıştır. Bu sözcüklerin belirlenebilmesi için ihtiyaç analizi gerçekleştirilmiş ve katılımcıların da katkısıyla kullanım oranı en fazla olan, öğrencilerin en sık karşılaştıkları ve ders kitaplarında en çok yer alan sözcükler bu sözlük okuma grubuna dâhil edilmiştir. Belirlenen sözcüklerin anlamlarına ulaşmak için sırasıyla TDK'nın 'Büyük Türkçe Sözlük'ü, D. Mehmet Doğan'ın 'Doğan Büyük Türkçe Sözlük'ü ve son olarak İlhan Ayverdi'nin 'Misalli Büyük Türkçe Sözlük'ü kullanılmıştır. Böylelikle sözcüklerin anlamları için farklı kaynaklara başvurulmuştur. Seçilen sözcüklerin birden fazla olan anlamları bu sözlüklerden okunmuş ve her anlam için katılımcılarla karşılıklı tartışılmış ve yorumlamalar gerçekleştirilmiştir. Sözcüklerin her anlamı için tanıklama cümleleri okunup, bu cümlelerin sahipleriyle ilgili öğrencilere bilgiler verilmiştir. Tanıklama cümlelerinin sahipleri de büyük oranda Türk kültürüne mal olmuş tanınmış şair ve yazarlardan oluşmaktadır. Böylelikle kullanım sıklı̆̆ı fazla olan sözcüklerin öğretiminin yanında, seçkin yazar ve şairler konusunda da bir farkındalık kazandırmak amaçlanmıştır. Çalışmada okuması gerçekleştirilen sözcüklere "çıkmak, geçirmek, kıymak, kapatmak, düşlemek..." örnek olarak verilebilir.

\section{Bulgular}

Temelar altında, katılımcıların görüşme sorularına verdikleri cevaplara göre kodlar oluşturulmuş ve aşağıda yer alan tablolarda belirtilmiştir. Bu tablolarda hangi öğrencinin hangi koda yönelik cevap verdiği ve frekansları gösterilmiştir. Daha sonra örnek cümlelerin paylaşımı yapılmış ve bunlara yönelik yorumlamalar eklenmiştir.

Tablo 2

Türkçeyi İkinci Dil Olarak Öğrenen Öğrencilerin Sözlük Okuma Yöntemine İlişkin Görüşleri

\begin{tabular}{|c|c|c|c|c|c|c|c|c|c|c|c|c|}
\hline 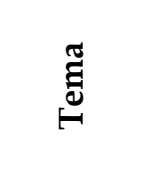 & $\ddot{0}$ & $\frac{\vec{z}}{\frac{\pi}{2}}$ & 胥 & صี & : & 芯 & $\stackrel{\check{\partial}}{.}$ & Ō & $\begin{array}{l}\text { స్ } \\
\text { స్ } \\
\approx \\
\approx\end{array}$ & ڤే & 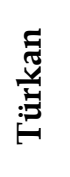 & 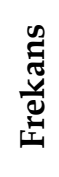 \\
\hline \multirow{6}{*}{$\begin{array}{c}\text { Sözlük } \\
\text { okuma } \\
\text { süreci } \\
\text { ve } \\
\text { yararları }\end{array}$} & Faydalı & * & * & * & * & * & * & * & * & * & * & 10 \\
\hline & $\begin{array}{l}\text { Taniklama } \\
\text { cümlesi }\end{array}$ & * & * & & * & * & * & * & * & & * & 8 \\
\hline & $\begin{array}{c}\text { Farklı } \\
\text { anlamlar }\end{array}$ & * & & * & * & & * & * & & * & * & 7 \\
\hline & İlginç & & & & & & * & & & * & & 2 \\
\hline & Eğlenceli & & & & & & * & & & & & 1 \\
\hline & Yorucu & & & * & & & & & & & & 1 \\
\hline
\end{tabular}

Tablo 2 incelendiğinde sözlük okumanın söz varlığına etkisine yönelik çeşitli görüşler tespit edilmiştir. Bu hususlardan ilki, okuma sürecinin katılımcılar için faydalı olduğu ve sözcüklerin her bir anlamı için kullanılan tanıklama cümlelerinin, 
öğrencilere Türk kültürüne yönelik olarak fazladan bilgi sağladığ1 yönündedir. Bu konuyla ilgili olarak Bekir "Bazı kelimeler bilmiyorsun. Bildĭğin vakit olsa bile karşı tarafa anlatamıyorsun. Hemen sözlüğe bakıyorsun. 'Aaa, evet buydu!' diyorsun. Çok faydalı oluyor. Farkl yerlerde, farklı kelimeler söylememi bile öğretiyor. Burada kullanabilirim diyorum." cümleleriyle sözlük okuma sürecinin kendisine faydalı olduğunu, süreç içerisinde örnek uygulamalar gerçekleştirilirken yaşanılan durumlarla ilgili örnek vermiştir. Onunla benzer görüşler bildiren Bahar ise "Sözlük kitap okumalarımız çok faydah oldu. Yani bir kelimenin başka anlamları olduğunu görüyorum. Sonra onu arkadaşlara söylüyorum. Onlar anlamıyor. 'Sen ne diyorsun?' diyorlar. Ben de onlara anlatıyorum." sözlerini sarf ederek tıpkı diğer katılımcı gibi sürecin fayda sağladığını belirtmiş; ona ek olarak ise günlük hayatından bir örnek vererek sözcükleri başka alanlarda nasıl kullanabildiğine dair bilgilendirme yapmıştır. Katılımcıların süreçle ilgili olarak üzerinde durdukları bir diğer konu olan tanınmış yazar ve şairlere ilişkin olarak Ergül ise "Örnek cümlelerin sahiplerini de öğrendik. Hepsini bilmiyorum ama beğendiğimi yazdım kâğıda. Namık Kemal' in sözü güzeldi. Ben Suriyeli olduğum için buraya geldim. Orda da 'Niye vatandan çıktınız?' dedi." sözleriyle hem seçkin bir yazarı öğrenebildiğini Namık Kemal örneğiyle paylaşmış hem de kendi hayatıyla yazarın cümlesi arasında bağ kurabildiğini vurgulamıştır (Katılımcının sözünü ettiği örnek ise Namık Kemal'in şu sözüdür: Ya niçin vatanınızdan çıktınız?). Bu hususla ilgili olarak görüş bildiren bir diğer katılımc1 ise Ramazan olmuştur. Ramazan "Bazı cümleler anlaması zordu ama iyi ki onlara da baktık. Ben edebiyat okuyacağım. Ondan bu kişileri bilmek iyi oldu benim için." ifadeleriyle tanıklama cümlelerinin bir kısmının zor olsa da bunların işine yaradığını belirtmiş ve hedefleriyle öğrendikleri arasındaki paralellikten dolayı kazançta olduğunu aktarmıştır.

Tablo 2 incelendiğinde, öğrenci görüşlerine göre ulaşılan bir diğer veri ise sözlük okumanın, sözcüklerin farklı anlamlarını öğrenmeye fırsat tanıdığı olmuştur. Katılımcılara göre sözlük okumak, sözcüklerin diğer anlamlarını kavrayabilmek açısından etkili olmuş ve günlük hayatta kavrayamadıkları cümleleri bu uygulamadan sonra anlayabildiklerini belirtmişlerdir. Nitekim Türkan "Mesela atmak kelimesinin başka anlamları olduğunu da bildik. Sözcüklerin sadece bir anlamı değil de bazı yerlerde iki-üç anlamlı oluyormuş. Yeni anlamlar beni çok şaşırttı. Tuz koymalıyız. Ama tuz atmak da olurmuş." cümleleriyle sözlük okuma uygulamasının sözcüklerinin birden fazla anlamının olduğunu kavramasına yardım ettiğini belirtmiştir. Aykut da Türkan gibi sözcüklerin farklı anlamlarını bu uygulamada anladığını söyleyerek, "Türkçede çok fazla anlam var. Yani aynı anlamı var. Önceden bilmiyordum. Diyordum ki bir kelime bir anlamı var. Şimdi anladım ki bir kelime kaç anlamı var. Aynı anlamı değil, başka yerde de kullanabiliriz." ifadeleriyle uygulama öncesinde sözcüklerin çok anlamlı olabileceğini bilmediğini ve sadece tek anlama yoğunlaştığını belirtmiştir. Bununla beraber katılımcılar daha önce de belirtilen tanıklama cümlelerine ilişkin farklı açılardan görüşler de sunmuşlardır. Tanınmış şair ve yazarları öğrenebilmenin yanında, bu cümleler vasıtasıyla sözcüklerin farklı anlamlarını daha rahat kavrayabildiklerini belirtmişlerdir. Örneğin bu durumla ilgili olarak Özge "Diyor ki 'Çocuğa bir tane geçirdi.' Bu kelimenin bir sürü anlamı varmış. Bazılarıyla karşılaştım bazılarıyla karşılaşmadım. Daha önce o kelimeyi (anlamı) hiç duymadım ama şimdi duymuş oldum." cümlelerini kurarak bazı sözcüklerin birden fazla anlamı olduğunu bilse de bu kadar fazla olduğunu bilmediğini belirtmiştir. İlker ise bu durumla ilgili olarak "Bu örneklerin çok faydası oldu. Bu ülkenin farkl cümleleri olduğunu bildim. Çok anlam olduğu için cümleleri de öğrenip 
kullandım." cümlelerini paylaşmış ve sözcüklerin olabilecek farklı anlamlarını süreç sonunda anlayabildiğini ve örnek cümle uygulamalarına hayatında yer verebileceğine değinmiştir.

Tablo 3

Türkçeyi İkinci Dil Olarak Öğrenenlerin Sözlük Okuma Yöntemi İle Okunan Sözcüklerin Sayısına İlişkin Görüşleri

\begin{tabular}{|c|c|c|c|c|c|c|c|c|c|c|c|c|}
\hline 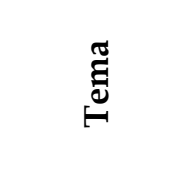 & $\ddot{z}$ & $\frac{\vec{z}}{\frac{\vec{z}}{2}}$ & 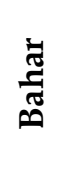 & $\frac{\Xi}{\bar{v}}$ & 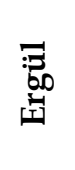 & 䔍 & 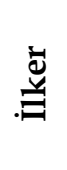 & $\begin{array}{l}\stackrel{8}{\circ} \\
: 0\end{array}$ & 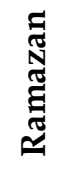 & ڤ్ & 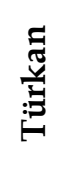 & 苞 \\
\hline & Yeterli & & & & * & & & & * & & & 2 \\
\hline \multirow{2}{*}{$\begin{array}{l}\text { Okunan } \\
\text { sözcüklerin } \\
\text { niceliği }\end{array}$} & Yetersiz & * & & * & & * & * & * & & * & * & 7 \\
\hline & Kararsız & & * & & & & & & & & & 1 \\
\hline
\end{tabular}

Tablo 3 incelendiğinde sözlük okuma yoluyla öğretilmeye çalış1lan sözcüklerin sayısına ilişkin öğrenciler iki farklı görüş belirtmiştir. Katılımcıların büyük çoğunluğuna göre süreç içerisinde üzerinde durulan sözcüklerin sayısı yetersiz olmuştur. Okunulan sözcük sayısının yetersiz olduğunu belirten Salim, "Bence daha fazla olabildiğini düşünüyorum. Her okuduğumda daha fazla olabilir diye düşünüyorum. Bu kadar değildir. Daha fazla okumalıydık. Daha fazla olması gerektiğini düşünüyorum yani. Çünkü azmış gibi görünüyor bence. Mesela bir daha gelecekteki derste öğrenecek ders diye düşünüyorum." cümleleriyle dönem boyunca üzerinde durulan sözcüklerden daha fazlası olabileceğini düşündüğünü, bundan dolayı da uygulamanın devam ettirilerek daha fazla sözcüğe yer verilmesi gerektiğini düşündüğünü vurgulamıştır. Hatice de tıpkı Salim gibi okunan sözcük sayısının az olduğunu belirterek, "Kelime sayısı yeterli değildi. Çünkü her okumada sözcük sayısı daha çok olmalıydı. Böylelikle çok kelime anlardık. Çünkü okulda, dışarda çok kelimeyle karşılaşıyoruz." sözleriyle her etkinlikte okunan sözcük sayısının daha fazla olması gerektiğini, çünkü gündelik hayatında çok fazla farklı sözcüklerle karşılaştığını belirterek okunan sözcük sayısının daha fazla olabileceğini söylemiştir. Büyük çoğunluğa rağmen bazı katılımcılar da okunan sözcük sayısının yeterli olduğunu ifade etmiştir. Örneğin bu durumla ilgili olarak Ramazan "Bence sözcük sayısı yeterliydi. Çünkü fazlası ezberlemek için zordu. Az olsun öğrenelim. Ama okumanın da daha olmasını istiyorum." şeklinde görüşlerini paylaşmış ve okunan sözcük sayısının yeterli olduğunu düşündüğünü söylemiştir. Çünkü ona göre sözcük sayısı ne kadar az olursa öğrenmesi de o kadar kolay olacaktır. 
Tablo 4

Türkçeyi İkinci Dil Olarak Öğrenenlerin Sözlük Okuma Yöntemi İle Okunan Sözlüklere ve Seviyeye Uygunluğuna İlişkin Görüşleri

\begin{tabular}{|c|c|c|c|c|c|c|c|c|c|c|c|c|}
\hline 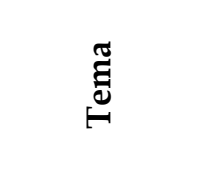 & 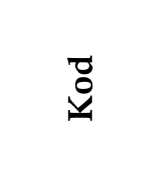 & $\frac{\bar{z}}{\frac{\pi}{2}}$ & 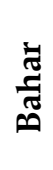 & صू & $\begin{array}{l}\bar{F}_{0} \\
\text { 至 }\end{array}$ & & 岂 & O: & 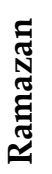 & ஸొ & 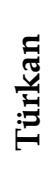 & 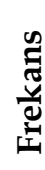 \\
\hline \multirow{6}{*}{$\begin{array}{l}\text { Sözlüklerin } \\
\text { niteliği ve } \\
\text { dil } \\
\text { düzeyine } \\
\text { uygunluğu }\end{array}$} & Zorluk & * & * & * & * & & * & * & * & * & * & 9 \\
\hline & $\begin{array}{c}\text { Farklı } \\
\text { açılklama }\end{array}$ & * & * & * & * & & * & * & & * & & 7 \\
\hline & $\begin{array}{c}\text { Sözlük } \\
\text { türü }\end{array}$ & & * & * & * & * & * & & * & & * & 7 \\
\hline & $\begin{array}{c}\text { Dil } \\
\text { seviyesi }\end{array}$ & & * & * & & * & & & * & * & & 5 \\
\hline & Siralama & & & & & * & * & & & & & 2 \\
\hline & Uzunluk & * & & & & & & & & & & 1 \\
\hline
\end{tabular}

Tablo 4 incelendiğinde katılımcıların okunan üç farklı sözlüğe ilişkin zorluk derecesine ilişkin görüşlerini belirttikleri görülmektedir. Örneğin Özge “Büyük kırmızı sözlük çok zordu. Örnekleri de okuması da problemliydi. Fakat bu mavi sözlük daha iyiydi. Rahat okunurdu." cümleleriyle sözlükleri okunabilirlik ve anlaşılabilirlik açısından yorumlamış ve kendine göre bir kolaylık-zorluk sıralaması yapmıştır (Katılımcının burada bahsettiği mavi sözlük TDK'nın 'Büyük Türkçe Sözlük'ü, kırmızı büyük sözlük dediği ise İlhan Ayverdi'nin tek ciltlik 'Misalli Büyük Türkçe Sözlük'üdür). Aykut ise "Şu TDK ve Doğan yazanları okumak ve anlamak daha iyiydi. Kırmızı da iyiydi ama o bize zordu." ifadeleriyle tıpkı Özge gibi düşündüğünü belirtmiş ve kırmızı sözlüğün ilerleyen aşamalarda tercih edilebileceğini dile getirmiştir (Katılımcının burada bahsettiği sarı sözlük ise Mehmet Doğan'ın 'Doğan Büyük Türkçe Sözlük'üdür). Haliyle katılımcılar sözlükler arasındaki anlaşılabilirlik bakımından kendilerine göre bir sıralama yapmışlar ve TDK'nın sözlüğünün kendi seviyeleri için okunmasının ve anlaşılmasının daha rahat olduğunu ifade etmişlerdir.

Tablo 4 incelendiğinde, çalışmanın geliştirilmesi sürecinde, katılımcıların ikinci dil olarak Türkçe öğretiminde konuya ve seviyeye uygun sözlüklerin üretilmesinin de önem arz ettiğini belirttikleri saptanmıştır. Tespit edilen bulgulara göre katılımcılar hem dil seviyelerine göre hazırlanacak sözcüklerin faydalı olacaklarını belirtmişler hem de atasözleri, deyimler, eş-zıt anlamlılar ve isimler gibi sözlüklerin geliştirilmesinin öğrenme kolaylığı sağlayacağını vurgulamışlardır. Dil seviyesine uygun sözlük hazırlanması görüşünü öne sunan Hatice "Bazı kelimeler anlamadım. Çünkü çok şey anlatıyor. Mesela 'tepesine çıkmak' vardı. Ben bunu başka anladım. Ama anlamı başka. Bunun gibi şeyleri anlamak için de bir sözlük gerek." şeklinde düşüncelerini paylaşmıştır. Hatice ile aynı doğrultuda görüş belirten Ergül ise "Çok kelimede gerçek yok. Yani 'üste çıkmak' diyor ama bunun mana yukarı değil. Daha başka. Bu kelimelere farklı bir sözlük mümkün." cümlelerini paylaşarak bu ve benzeri ifadeler için farklı bir sözlüğün Türkçenin ikinci dil olarak öğretilmesinde gerekli olduğunu belirtmiştir. Bu 
görüşlere ek olarak İlker "Kelimenin eş-zıt manası okumada vardı. Ama karışık oluyor ve anlamıyorum. Bu eş-zıt kelimeler başka sözlükte olabilir mi?" sözlerini ifade ederek eş ve zıt anlamlı sözcükler için ayrı bir sözlüğe de ihtiyaç olabileceğini vurgulamıştır. Ayrıca katılımclar seviyeye uygun sözlüklere de ihtiyaç olabileceğini ifade etmişlerdir. Örneğin Salim "Bazı kelimeler çok zor. Onlar çok fazla kullanmıyoruz. Böyle yüksek seviyede lazım onlar. O kelimeleri başka sözlüğe koymak gerek." düşünceleriyle seviyeye uygun sözlüklerin Türkçenin ikinci dil olarak öğretiminde yer alabileceğini belirtmiştir.

Tablo 5

Türkçeyi İkinci Dil Olarak Öğrenenlerin Sözlük Okuma Yönteminin Devamlılığına İlişkin Görüşleri

\begin{tabular}{|c|c|c|c|c|c|c|c|c|c|c|c|c|}
\hline 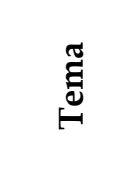 & : & $\frac{\frac{\pi}{\vec{z}}}{\frac{\lambda}{2}}$ & 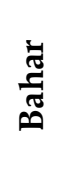 & 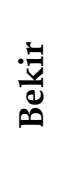 & 泀 & : & $\stackrel{\ddot{g}}{=}$ & : & 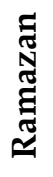 & ஸే & 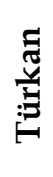 & 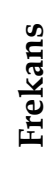 \\
\hline \multirow{4}{*}{$\begin{array}{l}\text { Sonraki } \\
\text { süreçte } \\
\text { sözlük } \\
\text { okuma } \\
\text { tercihi }\end{array}$} & $\begin{array}{l}\text { Devam } \\
\text { etmeli }\end{array}$ & * & * & * & * & * & * & & * & * & * & 9 \\
\hline & Seviye & & & & * & * & * & & * & * & * & 6 \\
\hline & Yardım & & & * & & & & & & & & 1 \\
\hline & Kararsız & & & & & & & * & & & & 1 \\
\hline
\end{tabular}

Tablo 5 incelendiğinde sözlük okuma yönteminin devam etmesine ve öğrencilerin kendilerinin de sözlük okumaya devam edeceğine dair verilere ulaşılmıştır. Bununla beraber sözlük okuma yönteminin özellikle B2 seviyesinden sonra olması gerektiğini de belirtmişlerdir. Sözlük okumanın gelecekteki derslerde de yapılması gerektiğini düşünen Türkan "Mutlaka bu etkinlikler yapılmalı. Onlar da bizim gibi sıfırdan geliyorlar. Burada gelişiyorlar, burada öğreniyorlar. Her cümleyi, her noktayı onlar da bilmeliler ki kelimeleri ögrensinler." ifadelerini kullanarak yeni gelecek öğrencilerin de kendileri gibi her şeye baştan başlayacakları için bu etkinliklerin onlara da yapılması gerektiğini söylemiştir. Bahar da Türkan'a benzer görüşler bildirmiş ve ona ek olarak "Onlar da okumal. Çünkü bu kelimeler sadece derslerde değil, günlük hayatımızda da çok yardımcı oluyor. O yüzden de onların da bu kelimeleri okumasını tavsiye ederim." şeklinde görüşlerini paylaşmıştır. Katılımcılar bireysel okumalarına da değinmişlerdir. Bu durumla ilgili olarak İlker "Mutlaka kendim de okurum. Çünkü bildiğimi bilsem bile başka yerde başka kelimelerin başka anlamlan olduğunu biliyorum. Kitap okuyorsam bildiğim şey bile olsa ardindan gelen kelime farkliysa, bu neden burada böyle oldu diye yine sözlükleri okurum. Yani diğer kelimeleri de okuyacağım." cümlelerini kurmuş ve süreç sonrasında da kendisinin müstakil olarak sözlük okumaya devam edeceğini belirtmiştir. Diğer bir katılımcı olan Bekir de sözlük okumaya devam edeceğini belirtmiş ve bu işe çok 1 sındığını vurgulamıştır. "Ben kendim de sözlük okurum. Çünkü ben okumayı çok seviyorum. Mesela bir arkadaşım o kelimeyle ilgili bir şey söylese ben ondan daha fazla söylemek için sözlük okurum. Böylece anlarım ve kullanırm." cümleleriyle de sözlük okumaya neden devam edeceğine dair bir bilgi vermiş ve sözlük okuduğu süre zarfında sözcükleri daha iyi anlayabileceğini ve kullanabileceğini ifade etmiştir. Salim 
de diğer katılımcılara benzer görüşler bildirmiş ve onlara ek olarak sözlük okuma yönteminin özellikle orta seviyelerden itibaren gerçekleştirilmesinin daha verimli olacağını vurgulamıştır. Nitekim "Sözcük çok anlam var. Bunu anlamak zor oldu önce. Lakin B1, B2 daha iyi okumak için. C1 en iyi." ifadeleriyle öğrenilen sözcüklerin birden fazla anlamının olmasının süreci zorlaştırdığını ve mümkünse sözlük okumalarının özellikle ileri seviyedeki dil gruplarında yapılması gerektiğini vurgulamıştır. Salim ile aynı düşünceye sahip olan Ergül ise "Bence sözlük okuma ortadan olmal. Misal B1. Çünkü biz B1 başladık ve öğrendik. B2 en güzeldi." şeklinde düşüncelerini dile getirmiş ve sözlük okumak için en uygun seviyelerin orta seviyelerden itibaren olması gerektiğini belirtmiştir.

Video kayıtları yoluyla ulaşılan veriler incelendiğinde ise ulaşılan ilk bulgu öğrencilerin sözlük okuma sürecine katılım derecelerinin yüksek olduğudur. Video kayıtlarının detaylı analizi yapıldığında, süreç başından süreç sonuna doğru katılımcıların sözlük okumalara ilgisinin günden güne arttığ1 tespit edilmiştir. İlk başlarda okumalara karşı katılımcılar çekingen davranmış ve çoğu kez sadece sözcükleri dinleyip kafalarıyla onaylamakla yetinmişlerdir. Uygulamayı algılamakta problem yaşamış ve sözcüklerin anlamları hakkında çoğunlukla yorumda bulunamamışlardır. Bazı anlamları birbiriyle karıştırmış ve çoğunlukla ya yanındaki arkadaşından yardım almaya çalışmış ya da çok fazla soru sorarak sürecin sekteye uğramasına neden olmuşlardır. Fakat süreç ilerledikçe hem uygulamanın işleyişine yönelik bilgi sahibi olup ortama uyum sağlamışlar hem de uygulamaya katılım oranları gözle görülür bir şekilde artmıştır. Zamanla sözcüklerin her anlamını kendileri okuyup yorumlamak istemişler, her anlam için kendileri de bir örnek vermeye çalışmışlardır. Yeri geldiğinde sözcüklerin anlamları için arkadaşlarıyla karşılıklı diyalog kurup yorumlamalarda bulunmuşlardır. Bununla beraber sözcükleri daha iyi anlatabilmek ve kavrayabilmek için mini canlandırmalara başvurmuşlardır. Her uygulama sonrasında ise süreç başında planlanmayan bazı sözcüklerin de gelecek okumalarda uygulamalara dâhil edilmesini istemişlerdir. Ayrıca video kayıtlarının bazı kısımlarında, sözlük okuma uygulamasının nasıl geçtiğini anlamadıklarını belirtip bu uygulamaya daha fazla zaman ayırılması gerektiğini belirtmişlerdir.

Video kayıtları yoluyla ulaşılan bir diğer bulgu ise öğrencilerin sözlüğü kullanma yeterliklerinin günden güne arttı̆̆ı tespit edilmesi olmuştur. Özellikle süreç başında katılımcılar sözlüğün sadece ilk anlamına bakıp geçmeye çalışmış, diğer anlamlara bakma gereği duymamışlardır. Bununla beraber günlük hayatta çoğunlukla internet ortamındaki popüler çeviri sitelerini veya cep telefonlarında yüklü olan sözlük uygulamalarını kullandıkları için somut bir sözlükte neler olabileceğine dair fikirlerinin çok olmadığı saptanmıştır. Hatta bazen sözlük okuması gerçekleşirken bazı katılımcıların gizlice telefondan sözcüğün anlamına bakmaya çalıştıkları tespit edilmiştir. Bununla beraber sözcüğün anlamına baksalar bile tanıklama cümlelerine bakmadıkları görülmüş ve genel olarak bir an önce okuyup geçme isteğinin katılımcılarda bulunduğu belirlenmiştir. Fakat ilerleyen aşamalarda katılımcılarda sözlüğün nasıl kullanılacağına dair gelişmeler olduğu tespit edilmiş ve sözlüğü kullanma yeterliklerinin her uygulamada biraz daha arttığı saptanmıştır. Gerek sözcüklerin anlamlarını kavramak için tanıklama cümlelerini daha iyi okumaya başlamışlar, gerekse de sözcüklerin zorlandıklarını anlamlarının karşısına notlar almaya başlamışlardır. Hatta bazı öğrenciler yeri geldiğinde başka sözcüklere de 
değinmek istemişler ve süreçte bahsedilen sözcüğün bulunduğu ilgili sayfadaki başka sözcükler hakkında da konuşmuşlardır.

\section{Tartışma, Sonuç ve Öneriler}

Çalışmada, ikinci dil olarak Türkçe öğretiminde, öğretiminde söz varlığının sözlük okuma yoluyla geliştirilmesini B2 ve sonraki düzeylerdeki öğrenci görüşlerine göre değerlendirmek ve incelemek amaçlanmıştır. Bu amaç doğrultusunda, sözlük okuma süreci ve yararları teması altında faydalı, tanıklama cümlesi ve farklı anlamlar gibi kodlara ulaşılmıştır. Dolayısıyla katılımcıların, söz varlığının sözlük okuma yoluyla geliştirilmesi üzerine ifade ettiklerinde görüşlerinde sözlük okuma uygulamasının kendileri için faydalı olduğunu ve tanıklama cümleleri sayesinde Türk kültürünün önemli ve seçkin kişilerini tanıyabildiklerini belirttikleri tespit edilmiştir. Balaban (2014) sözlüklerin bakılıp geçilen bir nesne mi yoksa açllıp okunan bir eser mi olduğuna dair yaptığı araştırmada; sözlük okumanın yeni kelime öğretme konusunda, Türkçenin söz varlığını ve özelliklerini kavratma konusunda, okunulan sözcüklerin içselleştirilmesi ve kişilerin seçkin yazar ve şairlere aşinalık kazanması konusunda faydaları olduğu sonucuna, çeşitli alanyazın taramaları ile ulaşmıştır. Göçer ve Garip (2019), tanıklama cümlelerinin sözlükler için çok önemli olduğunu vurgulayarak seçkin yazarların eserlerinden cümlelerin kullanılmasının, öğrenilen sözcüğün kalıcılığını sağlayabildiği sonucuna ulaşmışlardır. Ayrıca bu tarzdaki tanıklama cümlelerinin bağlamdan hareketle sözcük öğrenmeye de olanak tanıyacağını ifade etmişlerdir. Dolayısıyla ulaşılan bu sonuçlar, çalışmanın da bulgusuyla benzerlik göstermektedir. Görüldüğü üzere sözlük okumanın hem sözcüklerin öğrenilip içselleştirilmesi hem de seçkin yazar ve şairlere aşinalık kazanılması konusunda faydası bulunmaktadır. Bundan dolayı verimli bir sözcük öğretiminin hedeflendiği ve Türk kültürünün aktarımının söz konusu olduğu durumlarda sözlük okumanın, öğrenci görüşlerine göre başvurulabilecek bir yöntem olduğu göze çarpmaktadır.

Sözlük okuma süreci ve yararları teması altında ulaşılan kodlara göre, katılımcıların, sözlük okuma yoluyla öğretilen sözcüklerin farklı anlamlarını kavrayabildikleri ve sözcüklerin her anlamı için kullanılan tanıklama cümlelerin kalıcılığı artırdığına değindikleri tespit edilmiştir. Her sözcüğün birden fazla anlamı olduğunu kavrayarak günlük hayatlarında kullanmaya başladıklarını ifade ettikleri, ayrıca bu sözcükler için kullanılan cümlelerin de aynı zamanda sözcüğü kavramalarına da yardımcı olduğunu vurguladıkları saptanmıştır. Alanyazına bakıldığında, Büyükikiz ve Hasırcı'nın (2013) da aynı sonuçlara değindikleri görülmüştür. Türkçenin ikinci dil olarak öğretiminde sözcük öğretimiyle ilgili bir değerlendirme yaptıkları çalışmalarında, sözcüklerin birden fazla anlamının olabileceği ve farklı kalıplarda farklı anlamlara gelebileceğinin unutulmaması gerektiği sonucuna ulaşmışlardır. Haliyle sözcüklerin tüm anlamlarının verilerek metin içerisinde yer alan cümlelerde de buna dikkat edilmesi gerektiğini belirtmişlerdir. Şenyiğit (2020) ise sözlü dilde en sık kullanılan sözcükleri belirleyerek yabancı dil olarak Türkçe öğrenenlere yardımcı olabilecek bir sözlük hazırlamayı amaçladığ1 çalışmasında, öğretilecek sözcüğün belirlenmesinden sonra hangi anlamlarının öğretileceğinin de önemli olduğunu vurgulamıştır. Cümlenin bağlamına göre sözcügüun büründüğü anlamın değişeceğini ifade ederek öğrencilerin sözcüğün birden fazla anlamını bilmesinin gerekli olabileceğine değinmiştir. Dolayısıyla öğrencilere öğretilecek anlamların, kelime derinliği açısından bir ölçüt olduğu 
sonucuna ulaşmıştır. Bu çalışmanın öğrenci görüşlerine göre ulaşılan bir bulgusu olan sözlük okumanın farklı anlamları kavratabilmesi ve çeşitli katkılarının olması, bahsi geçen çalışmaların sonucunda yer alan kısımla paralellik göstermektedir. O hâlde sözcüklerin farklı anlamlarının öğretilmeye çalışıldığı ve cümle içerisinde farklı kalıplardan faydalanarak örnekler verilmesi gerektiğinde sözlük okumadan faydalanılabileceği, çalışmadaki cevaplardan ulaşılan temalardan ve kodlardan hareketle anlaşılmaktadır.

Okunan sözcüklerin niceliği teması altında yeterli, yetersiz ve kararsız gibi kodlara ulaşılmıştır. Ulaşılan kodlara göre katılımcılar, sözlük okuma sürecinde okunan kelimeleri yetersiz bulmuşlardır. Günlük yaşamda karşılaşabilecekleri sözcüklerin sayıca fazla olabileceğini dile getiren katılımcılar, uygulamada daha fazla sözcüğe yer verilirse bir problemle karşı karşıya kalmayacaklarını ifade etmişlerdir. McKeown (1985), yüksek ve düşük yetenekli öğrencilerin kelimenin anlamını bağlamdan bulabilmeleri üzerine yaptığı çalışmada, sözcük hazinesi zengin olan öğrencilerin, karşısına çıkan metinlerde bulunan sözcüklerin anlamını bulmada veya tahmin etme konusunda daha başarılı olabilecekleri sonucuna ulaşmıştır. Gülseren ve Batur (2009) da yaptıkları çalışmada sözlük okuma alışkanlığının öğürencilerin sözcük hazinesini geliştireceğini belirterek bu gelişimin dört temel dil becerisine olumlu yansıyacağını ifade etmektedir. Bu durumun da dilin kullanımında kendini belli edeceğini söylemektedirler. Ayrıca Karatay (2007) da kelime öğretimine yönelik gerçekleştirdiği çalışmada öğrencilerin sözcük hazinesinin zenginleştirilmesinin dört temel dil becerisini geliştirmeye katkıda bulunduğunu belirtmektedir. Bu çalışmada da katılımcılar, ne kadar çok sözcük bilirlerse hayatlarında karşılaşabilecekleri sorunların üstesinden o kadar rahat gelebileceklerini belirtmişlerdir. O hâlde bahsi geçen çalışmanın sonucundan da hareketle, sözlük okuma yapılırken mümkün olduğu kadar çok sözcüğe yer verilmeli ve öğrencilerin yaşamlarında karşılaşabilecekleri sözcüklere mümkün olabildiği kadar aşinalık kazandırılması gerektiği öğrenci görüşlerinden anlaşılmaktadır.

Sözlüklerin niteliği ve dil düzeyine uygunluğu teması altında zorluk, farklı açıklama, sözlük türü ve dil seviyesi gibi kodlara ulaşılmıştır. Ulaşılan kodlara göre katılımcıların ikinci dil olarak Türkçe öğretiminde konuya ve seviyeye uygun sözlüklerin üretilmesinin önem arz ettiğini belirttikleri saptanmıştır. Tespit edilen bulgulara göre katılımcılar hem dil seviyelerine göre hazırlanacak sözcüklerin faydalı olacaklarını belirtmişler hem de atasözleri, deyimler, eş-zıt anlamlılar ve isimler gibi sözlüklerin geliştirilmesinin öğrenme kolaylığı sağlayacağını vurgulamışlardır. Maden ve Demir (2019) de sözlük kullanma alışkanlığı kazandırmaya dair tespitler yaptıkları çalışmalarında, konuya uygun türde (eş zıt anlamlılar, kavramlar, isimler, terimler sözlüğü gibi) ve seviyeye uygun okul sözlüklerinin kullanımına özen gösterilmesi gerektiği önerilerinde bulunmuşlardır. Ayrıca Tüm (2017) yabancıların Türkçe öğrenme sürecinde tercih ettikleri sözlüklere yönelik gerçekleştirdiği çalışmada yabancı dil öğretilirken yabancı öğrencilerin itiyaçlarına yönelik sözlükler hazırlanması gerektiğini de vurgulamıştır. Ayrıca hazırlanacak bu sözlüklerin öğrencilerine seviyesine uygun (A1-C2) bir biçimde oluşturulması gerektiğini vurgulamıştır. Aynı şekilde Kardaş (2016) da yabancı öğrencilerin Türkçe öğrenme sürecinde sözlüklerden faydalanma durumunu ortaya koymayı amaçladiğı çalışmasında, yabancı öğrencilerin sözlük kullanma konusunda bilinçlendirilerek dil 
seviyelerine uygun sözlüklerden yararlanma becerisinin kazandırılması gerektiği sonucuna ulaşmıştır. Dolayısıyla bu çalışmanın bulgusu ile ilgili çalışmaların sonuç ve önerilerinin benzerlik gösterdiği söylenebilir. O hâlde Türkçenin ikinci dil olarak öğretiminde de sözcük hazinesinin geliştirilebilmesi için öğrencilerin kullanacakları sözlüklerin konuya ve seviyeye uygun türde olması gerektiği ilgili çalışmalardan ve öğrenci görüşlerinden anlaşılmaktadir.

Sözlük okuma tercihi teması altında devam etmeli, seviye, yardım ve kararsız kodlarına ulaşılmıştır. Ulaşılan kodlara göre katılımcıların her ne kadar uygulama bitse de sözlük okumaya devam edeceklerini belirttikleri saptanmıştır. Ayrıca katılımcılar, tek dilli sözlük okumaya devam edeceklerini ifade etmişlerdir. Alanyazına bakıldığında bu sonucun önemli olduğunu belirten Bingöl (2006), sözlük ve sözlükçülük üzerine yaptığı bir araştırmada bazı durumlarda tek lisanlı sözlüğün, iki lisanlı sözlüğge göre daha yararlı olduğunu ifade etmektedir. Halat ve Fırat (2021) da Türkçeyi yabancı dil olarak öğrenenlerin gerek sınıf içi gerekse de sınıf dışında sözlük kullanımına ilişkin görüşlerini araştırdıkları çalışmalarında, tek dilli sözlüklerin, iki dilli sözlüklere göre daha yararlı olduğunun söylenebileceği sonucuna ulaşmışlardır. Buradan ve öğrenci görüşlerinden de anlaşılmaktadır ki öğrencilerin dilin inceliklerine ve değişik kavramlarına hâkim olmaları istenen durumlarda tek dilli sözlük okuma yoluna gidilebilmektedir.

Tüm bu araştırmalar ve öğrenci görüşlerinden ulaşılan bulgular 1şı̆̆ında sözlük okuma ile ilgili şu öneriler sunulabilir:

- Türkçenin ikinci dil olarak öğretildiği öğrenme ortamlarında, öğrencilerin sözcük hazinesinin geliştirilmesi isteniyorsa sözlük okuma yöntemine başvurulabilir.

- Türk kültürüne ait şair ve yazarların tanıtılması amaçlanıyorsa, sözlüklerde yer alan tanıklama cümleleri sayesinde öğrencilere bu kişilere dair bilgilendirme yapılabilir.

- Türkçeyi ikinci dil olarak öğrenen öğrencilerin, zorunlu yaşam alanlarında işlerine yarayacak sözcüklerin öğretimi için sözlük okuma yöntemine başvurulabilir.

- Sözcüklerin öğreniminin daha kolay olabilmesi için Türkçenin ikinci dil olarak öğretiminde konuya ve seviyeye göre sözlükler geliştirilebilir.

- Sözlük okuma yönteminin başarıya ulaşabilmesi için öğrencilerin dil seviyeleri dikkate alınıp özellikle B2 ve sonraki düzeylerde bu yönteme başvurulabilir.

- Öğrencilerin, sözcüklerin sadece bir anlamını değil de mümkün olabildiğince fazla anlamını öğrenmeleri isteniyor ve bu sözcükleri çeşitli cümle kalıplarında anlayabilmeleri bekleniyorsa sözlük okuma yoluna gidilebilir. Çünkü sözlükler hem sözcüklerin birden fazla anlamını içermekte, hem de her sözcük için bünyesinde birer örnek cümle barındırmaktadır.

\section{Kaynakça}

Aksan, D. (1998). Her yönüyle dil, ana çizgileriyle dilbilim. Ankara: TDK Yayınları. Ayverdi, İ. (2011). Misalli büyük Türkçe sözlük. İstanbul: Kubbealtı Neşriyat.

Balaban, A. (2014). Sözlükler okunur mu? Sözlüklere bakılır mı? The Journal of Academic Social Science Studies, 24, 237-250. http:/ / dx.doi.org/10.9761/JASSS2189 
Barcroft, J. (2007). Effects of opportunities for word retrieval during second language vocabulary learning. Language Learning, 57(1), 35-56. https:// doi.org/10.1111/j.1467-9922.2007.00398.x

Bingöl, Z. (2006). Sözlük ve sözlükçülük üzerine bir araştırma. Akademik Bakış Dergisi, 9, 197-207

Büyükikiz, K. K. ve Hasırcı, S. (2013). Yabancı dil olarak Türkçenin öğretiminde sözcük öğretimi üzerine bir değerlendirme. Mustafa Kemal Üniversitesi Sosyal Bilimler Enstitüsü Dergisi, 10(21), 145-155.

Creswell, J. W. (2014). Nitel, nicel ve karma yöntem yaklaşımları-araştırma deseni (4. Baskıdan çeviri). ( S. B. Demir, Çev.) Ankara: Eğiten Kitap.

Crystal, D. and Crystal, H. (2000). Words on words: Quotations about language and languages. Chicago: University of Chicago Press.

Dağtan, E. (2015). Konuşma becerisinin öğretimi (ss. 333-350), Dil öğretimi (Editör: N. Bekleyen). Ankara: Pegem Akademi.

Fan, M.Y. (2003). Frequency of use, perceived usefulness, and actual usefulness of second language vocabulary strategies: A study of Hong Kong learners. The Modern Language Journal, 87(2), 222-241.

Göçer, A. (2010). Türkçe eğitiminde öğrencilerin söz varlığını geliştirme etkinlikleri ve sözlük kullanımı. Turkish Studies, 5(1), 1007-1036. http:/ / dx.doi.org/10.7827/TurkishStudies.1318

Göçer, A. ve Garip, S. (2019). Bă̆lam temelli kelime öğretiminde tanıklamalardan faydalanma: Türkçe sözlük'e 3 tür 3 tanık katkısı. 6. Uluslararası Multidisipliner Çalışmaları Kongresi (57-64). Gaziantep, Türkiye.

Göçer, A. ve Garip, S. (2021). Aktif sözcük dağarcı̆̆ının geliştirilmesinde sözlük okuma çalışmaları ve önemi. Uluslararası Alan Eğitimi Dergisi, 7(1), 112-130. http:/ /10.32570/ijofe.949218

Gülbahar, Y. ve Alper, A. (2009). Öğretim teknolojileri alanında yapılan araştırmalar konusunda bir içerik analizi. Ankara Üniversitesi Ĕ̆itim Bilimleri Fakültesi Dergisi, 42(2), 93-112.

Gülseren, C. ve Batur Z. (2009). Sözlüklerin niteliği ve işlevsel özelliği bağlaminda sözlük okuma alışkanlığının anadili becerilerine etkisi üzerine kuramsal bir $\begin{array}{llll}\text { yaklaşım. } & \text { Turkish } & \text { Studies, } & 4(4),\end{array}$ http:/ / dx.doi.org/10.7827/TurkishStudies.804

Güney, N. ve Aytan, T. (2014). Aktif kelime hazinesini geliştirmeye yönelik bir etkinlik önerisi: Tabu. The Journal of Academic Social Science, 5, 617-628. DOI: 10.16992/ ASOS.326

Güneş, F. (2013). Kelimelerin gücü ve zihinsel sözlük. Siirt Üniversitesi Sosyal Bilimler Enstitüsü Dergisi, 1, 1-24. DOI: 10.13159/susbid.33

Halat, S. ve Fırat, H. (2021). Yabancı dil olarak Türkçe öğretiminde sözlük kullanımına yönelik öğrenci görüşleri. Bayburt Ĕ̆itim Fakültesi Dergisi, 16(Özel say1), 148-165. http:/ /10.35675/befdergi.849926

Hall, E. (2002). Tony Harrison's Prometheus: A view from the left. Arion, 10(1), 129140.

Jalongo, M. R. and Sobolak, M. J. (2011). Supporting young children's vocabulary growth: The challenges, the benefits, and evidence-based strategies. Early Childhood Education Journal, 38(6), 421-429. DOI 10.1007/s10643-010-0433-x 
Johnson, A. P. (2015). Eylem araştırması el kitabı (2.Bask1), (Y. Uzuner ve M. Özten Anay, Çev.) Ankara: Anı Yayıncılık.

Kaplan, M. (2011). Kültür ve dil (4. Baskı). İstanbul: Dergâh Yayınları.

Karadağ, B. F. ve Göçer, A. (2018). Türkçenin yabancı dil olarak öğretiminde drama yönteminin akıcı konuşma üzerindeki rolü. Uluslararası Türkçe Edebiyat Kültür Ĕ̆itim Dergisi, 7(1), 431-446. http:/ / dx.doi.org/10.7884/teke.4142

Karatay, H. (2007). Kelime öğretimi. Gazi Ĕ̆itim Fakültesi Dergisi, 27(1), 141-153.

Kardaş, D. (2016). Türkçe öğrenen yabancı öğrencilerin sözlük kullanma tutum ve alışkanlıkları üzerine bir araştırma. Milli Ĕ̆itim, 210, 507-519.

Kolukısa, A. A. (2015). Yabancı dil öğrenim sözlükleri ve gerekliliği. Turkish Studies, 10(3), 653-672. http:/ / dx.doi.org/10.7827/TurkishStudies.7691

Korkmaz, Z. (1999). Oğuz Türkçesinin tarihî gelişme süreçleri ve Divanu Lugâti't Türk. Türk Dili, 570, 459-470.

Li, L. (1998). A study of dictionary use by Chinese university learners of English for specific purposes (Yayımlanmamış yüksek lisans tezi). Exeter University, Exeter.

Maden, S. ve Demir, R. (2019). Ortaokul Türkçe dersi öğretim programlarında sözlük kullanma alışkanlığı kazandırmaya dair tespitler. Mersin Üniversitesi Ĕ̆itim Fakültesi Dergisi, 15(2), 419-43. https:/ / doi.org/10.17860/mersinefd.533593

Maskor, Z. M. and Baharudin, H. (2016). Receptive vocabulary knowledge or productive vocabulary knowledge in writing skill, Which one important? International Journal of Academic Research in Business and Social Sciences, 6(11), 261271. http:/ / dx.doi.org/10.6007/IJARBSS/v6-i11/2395

McCarten, J. (2007). Teaching vocabulary: Lessons from the corpus, lessons for the classroom. Cambridge: Cambridge University Press.

McKeown, M. G. (1985). The acquisition of word meaning from context by children of high and low ability. Reading Research Quarterly, 20(4), 482-495. https:/ / doi.org/10.2307/747855

Merriam, S. B. (2013). Nitel araştırma - desen ve uygulama için bir rehber. (S. Turan, Çev.) Ankara: Nobel Yayıncilık.

Miles, M. B. ve Huberman, M. A. (1994). An expanded sourcebook qualitative data analysis. London: Sage Publication.

Nation, P. (2005). Teaching vocabulary. Asian EFL Journal Quarterly, 7(3), 47-54.

Patton, M. Q. (2014). Nitel araştırma ve değerlendirme yöntemleri (M. Bütün ve S. B. Demir, Çev.) Ankara: Pegem Akademi.

Read, J. (2004). Research in teaching vocabulary. Annual Review of Applied Linguistics, 24, 146-161. DOI: 10.1017/S0267190504000078

Schmitt, N. (2008). Instructed second language vocabulary learning. Language Teaching Research, 12(3), 329-363. https:/ / doi.org/10.1177\%2F1362168808089921

Şen, Ü. (2019). Dil eğitiminin genel kavramları. Ülker Şen (Ed.), Dil eğitiminin temel kavramları içinde (s. 1-20). Pegem Akademi.

Şenyiğit, Y. (2020). Yabancılara Türkçe öğretiminde sözlü dilin kelime sıklı̆̆ı ve A1-A2 seviye sözlüğ̈̈ (Yayımlanmamış doktora tezi). Sakarya Üniversitesi/ Eğitim Bilimleri Enstitüsü, Sakarya.

Tüm, G. (2017). Yabancilarn Türkçe öğrenme sürecindeki sözlük tercihleri. 1.Uluslararas1 İpek Yolu Akademik Çalışmalar Sempozyumu Bildiri Tam Metin Kitabı, 256264. Nevşehir. 
Yin, R. K. (2009). Case study research- design and methods (4th Edition). California: SAGE Publications.

\section{Summary}

\section{Introduction}

In expressing their feelings and thoughts, individuals' vocabulary is as important as their ability to address because vocabulary is very important in using the language effectively. A person's vocabulary consists of active and passive vocabulary. It is the active vocabulary that provides efficient communication. Various activities are carried out to improve active vocabulary. These are in the form of teaching words. There are various methods used in teaching vocabulary. Dictionary reading method is one of them.

"Unfortunately, the issue of dictionary reading has not been addressed as a separate topic until now. However, this issue should have been discussed by now." (Balaban, 2014, p.241) since reading dictionary improves the interpretation power of the individual. Each word read adds depth to a person's thinking skill, both with its usage area and with its multiple meanings. Dictionary reading method can also be used to enrich students' vocabulary in teaching Turkish as a second language. Because Nation (2005) states that it is necessary to allocate time to enrich the vocabulary and to decide which elements will be taught while teaching the word. Therefore, it is necessary to focus on words in order to increase the vocabulary in teaching Turkish as a second language.

\section{Method}

The research was carried out through the case study design, which is a design of the qualitative research method. The holistic single case design was preferred in the study. Participants of the study were determined according to easily accessible situation sampling, which is one of the purposeful sampling types. The study group consisted of ten students studying Turkish in Erzincan Binali Yildirim University TOMER. In the study, it was aimed to prevent possible mistakes that may occur when only one data collection tool is used by using more than one data collection tool. In this context, interviews and video recordings were used as data collection tools. Content analysis was used to analyze the data of the study. In the study, various precautions were taken and care was taken to avoid any damage to its validity and reliability.

\section{Results}

Various data were obtained through semi-structured interviews and video recordings on the acquisition of words through dictionary reading in teaching Turkish as a second language. When the data obtained through semi-structured interviews are examined, the participants can effectively benefit from the dictionary reading process, learn most of the words emphasized, find the number of words to be taught insufficient in the process, continue to read the dictionary even after the activity process is over, and activity the dictionary reading practice in future lessons. In addition to these, they also shared their personal views on the understandability of the dictionaries used in the process. When the data obtained through video recordings were examined, it was found that the students' participation in the dictionary reading process was high and 
their ability to use the dictionary increased day by day. Along with these, it was determined that they established a meaningful relationship regarding the use of the words learned in daily life.

The participants were able to use these words in different places and had the opportunity to get to know the famous persons of Turkish literature. According to the participants, reading a dictionary was effective in comprehending other meanings of words, and they stated that they could understand sentences that they could not understand in daily life after this practice. According to the majority of the participants, the number of words emphasized during the process was insufficient. According to them, since the number of words they encounter in daily life is higher, more words should be included in the activity process. Stating that they liked the method of teaching words through dictionary reading, the participants also stated that this method should continue for the teaching of words, but the dictionary reading method should be especially after the B2 level.

\section{Discussion}

Balaban (2014) in his research on whether dictionaries are an object to be looked through or a work to be opened and read; he concluded that dictionary reading is beneficial in teaching new words, understanding the vocabulary and features of Turkish, internalizing the words read, and gaining familiarity with distinguished writers and poets. Therefore, this result is similar to the result of the study. In their study, Maden and Demir (2019) made some findings about gaining the habit of using a dictionary and suggested that attention should be paid to the use of school dictionaries (synonyms, antonyms, concepts) that are appropriate for the subject and level. Therefore, it can be said that the finding of this study is similar to the recommendation of the study. Therefore, it can be seen from the relevant studies that the dictionaries that students will use in order to improve the vocabulary in teaching Turkish as a second language should be appropriate for the subject and the level.

\section{Pedagogical Implications}

In learning environments where Turkish is taught as a second language, dictionary reading method can be used if it is desired to improve the vocabulary of students. If it is aimed to introduce the poets and writers of Turkish culture, students can be informed about these people through sample sentences in the dictionaries. Dictionaries can be developed according to the subject and level in the teaching of Turkish as a second language so that the learning of the words is easier. In order for the dictionary reading method to be successful, this method can be used, especially at B2 and higher levels, by considering the language levels of the students. If students are asked to learn not only one meaning of the words, but as many meanings as possible, and if they are expected to be able to understand these words in various sentence patterns, a dictionary reading can be used. Because dictionaries both contain more than one meanings of the words and also contain an example sentence for each word.

\section{Araştırmanın Etik Taahhüt Metni}

Yapılan bu çalışmada bilimsel, etik ve alıntı kurallarına uyulduğu; toplanan veriler üzerinde herhangi bir tahrifatın yapılmadı̆̆ı, karşılaşılacak tüm etik ihlallerde 
“Cumhuriyet Uluslararası Eğitim Dergisi ve Editörünün” hiçbir sorumluluğunun olmadığı, tüm sorumluluğun Sorumlu Yazara ait olduğu ve bu çalışmanın herhangi başka bir akademik yayın ortamına değerlendirme için gönderilmemiş olduğu sorumlu yazar tarafından taahhüt edilmiştir.

Çalışma, 2020 yılı öncesi araştırma verileri kullanılmış olması sebebiyle etik kurul izni gerektirmeyen çalışmalar arasında yer almaktadır.

\section{Yazar Bilgileri /Authors' Biodata}

Ali GÖÇER Erciyes Üniversitesi'nde Prof. Dr. olarak görev yapmaktadır. Çalışma alanları Türkçe eğitimi, Türkçenin yabancı/ikinci dil olarak öğretimi, Türk dili ve edebiyatı eğitimi, öğretmen yetiştirme ve Türkçe eğitiminde ölçme ve değerlendirmedir.

Ali Göçer He works as a Prof. Dr. at Erciyes University. His fields of study are Turkish education, teaching Turkish as a foreign/second language, Turkish language and literature education, teacher training and measurement and evaluation in Turkish education.

Bilal Ferhat KARADAĞ Erzincan Binali Yıldırım Üniversitesi'nde Arş. Gör. olarak çalışmaktadır. Çalışma alanları Türkçe eğitimi, Türkçenin yabancı/ikinci dil olarak öğretimi ve öğretmen yetiştirmedir.

Bilal Ferhat Karadağ He works as a research assistant at Erzincan Binali Yıldırım University. His fields of study are Turkish education, teaching Turkish as a foreign/ second language and teacher training. 